\title{
A Comparative Study of English Taboos and Euphemisms
}

\author{
YANG HUA* \\ Department of Foreign Languages, Sichuan University of Science and Engineering, Zi Gong 643000, China \\ *Corresponding Author: YANG HUA, Department of Foreign Languages, Sichuan University of Science \\ and Engineering, Zi Gong 643000, China
}

\begin{abstract}
Language is an inevitable outcome of the development of human society and a response to social life. The development of society promotes the evolution and evolution of language. With the development of society, in real life, people have taboos on certain things and behaviors for various reasons. Over time, they become taboos. Their expressions in language are called taboo words. The development of society and the existence of taboo words have prompted the emergence of euphemism. Every country and every nation has its own taboos and euphemisms, which also profoundly reflect the development and changes in society. This article will take the taboos and euphemisms in English as an example, and make a brief analysis from the classification, connection and difference between the two.
\end{abstract}

Keywords: taboos; euphemisms; classification; connection; difference

\section{INTRODUCTION}

Language is the carrier of culture and an important part of the culture. Not only can language convey information, but it is also a social phenomenon as well as a social behavior. Taboos and euphemisms are two common and closely related language phenomena, and they are also a common cultural phenomenon. In daily communication, people always have different ideas. Sometimes they are unwilling or unable to express their wishes directly, thus in this way taboos are produced. Euphemism becomes the best choice for expression when thinking about how to accurately express things or things that people don't want to express directly. Therefore, some scholars have studied taboos and euphemisms from many angles. Most of them tend to discuss the contrast between taboos and euphemisms in English and Chinese and ignore the comparative analysis of the phenomena of the two languages themselves. Therefore, this paper focuses on a more objective analysis of the two language phenomena. The purpose is not only to help people have a better and more comprehensive understanding of the two language phenomena, but also to help people make scientific, accurate and reasonable distinctions between the two, and to make people aware of the big differences between taboos and euphemisms.

\section{LITERATURE REVIEW}

The word "taboo" is collectively referred to as "tabu" and translated into "taboo" or "tabu" in English, which means" sacred and untouchable". The word derives from the dialect of the Polynesian Islands in the Central Pacific Ocean. It is said that James Cook, an Englishman, encountered many peculiar social phenomena in the Tonga Islands in the South Pacific in 1777. On this island, some things are only used by noble people such as gods, kings, monks, chiefs and so on, while ordinary people are forbidden to use them. Ordinary people can't get close to something, and ordinary people can't say some names and words. Therefore, with the development of society, these sacred or filthy things are among the taboos of people. Once people commit taboos, it is said that punishment or retribution will be incurred.

Therefore, taboos mainly include two aspects, one is the worship of language, the other is the prohibition or substitution of language. With the development of society, the term "Tabu" has gradually entered the field of anthropology, ethnology, and sociology, and is widely used. As a result, "Taboo" has attracted public attention, because it is closely related to people's daily life, but also reflects people's social life and psychological value. Taboos have gradually become taboos in all 
aspects of human life. For example, people's taboos on the names of gods and saints, on people's life, age, illness and death, and on curses and curses. There are also many taboos in English, such as the word "cock". English beginners all know the meaning of "cock", but in American there is the meaning of "male genital organs", so we cannot use this word casually, while "cock" has another more formal expression: "rooster", so if we want to express "I was born in the Year of the Chicken". I was born in the year of the rooster. In addition, "God, Christ" and other words cannot be blurted out, because most of the British are devout Christians.

In The Attempting Discussion of English Taboos, the author Zhuang Hecheng divides taboo words into three categories: profane words, obscene words and words against good taste. Profane words are about deity and religion, and only using them on religious occasions or formal occasions can be accepted completely. Many Orthodox Jews even avoid using the word "god", like a Jewish student writes g-d of medicine instead of god of medicine. Obscene words are much more serious than profane words, and in a sense, obscene words are considered an offense against ethics. Obscene words are often about sexual organs and sexual behaviors, like screw, balls, prick, etc. These words cannot be used for writing and in spoken in any language and any culture for the social convention and traditional concept, not even in the liberated society in the western world. But beyond that, obscene words are also used for strengthening the energy in language or curing and abusing, such as fuck you, bugger off. Another taboo words are those words against good taste, and the typical words are those about excretion, such as piss, shit, crap. The topics refer to caducity, disease, death, poverty are usually taboo for western people, thus some words related to these topics become taboo words, such as using Big $\mathrm{C}$ or terminally ill instead of cancer.

The word "Euphemism" comes from the Greek language. "Eu" means "good" while "phemism" means "language, discourse". Therefore, "Euphemism" literally means "speak with good words or in a pleasant manner". So the expression of euphemism means using a pleasant, Euphemistic and vocal words to replace unpleasant, rude, harsh words. Taboo can be used, but words cannot be said, meaning cannot be expressed. Therefore, with the development of social civilization, euphemism, as a language to replace taboos, has come into being. As From kin said, "The existence of taboo words or taboo ideas stimulates the creation of euphemism. A euphemism is a word or phrase that replaces a taboo word, or that is used in the attempt to avoid either fearful or unpleasant subjects." So euphemism itself began to transform into taboo from the moment it was created. For example, people in the English world do not dare to use the name of God without fear of a major disaster, so they seek ethics and seek communication. The purpose is to use Jeepers creepers and gosh darn instead of Jesus and God damn. In the West, people rarely talk about age, especially women. The main reason is to avoid old age because old age means youth is absent, meaning economic status and the decline of political status, so the word old is generally unacceptable, so there is the emergence of euphemism for the elderly. From these explanations, we can clearly know that euphemism is mainly based on human psychology. Euphemism is not only a linguistic phenomenon, but also a cultural phenomenon, but also a social phenomenon, which reflects the values, aesthetics, and virtues of society.

Euphemism is indirect, pleasant, polite, and mild. And from the knowledge in our minds we may find that euphemism is closely related to taboo. When giving up a taboo word, people will find another word to replace it, which creates a euphemism. In English language, euphemism is widely used in the daily communications. And in English language, we have many ways to express euphemism. And those ways can be categorized into three classifications. The first is through the change of our speech sounds, for instance, we usually say "Gosh" instead of "God". The second way is semantic method, such as synonymy, negation and vague expressions. And the last method is using kinds of figures of speech, for example, understatement, metaphor and metonymy. And this thesis mainly focuses on the classification, connection, differences and functions of English taboos and euphemism as well as its significance on English learners.

\section{THE ClaSSIFICATION OF ENGLISH TABOOS AND EUPHEMISMS}

\subsection{The Classification of English Taboos}

There seem to be some taboo words in every language, which are always limited to some certain aspects, and English is no exception. Many contraindications involve human excretion, sexual behavior, illness, and death. As for taboo words, different dictionaries often use different methods of processing. The main English taboo words can be roughly divided into three categories: sacred words, sly words, and insulting words. Some examples of the three taboo categories are as follow. 
The so-called blasphemy is that for some people, because of the reasons of faith, some words such as "God, Jesus", are regarded as sacred and inviolable, only in the formal and solemn occasions, or under religious occasions can these words be used.

Most of the defamatory words are related to sex. Such words are regarded as filthy words, taking "Fuck you", "Bugger off" as examples. Lady Chatterley's Lover, one of the most controversial English novels of the 20th century, is well known for its many obscene words and chapters describing sex. This novel caused a great disturbance and was later banned.

When it comes to words that are injurious, they mainly refer to abusive words involving human excretion. The abusive words are mainly animal names, , such as "bitch, pig, cow" and other words. There are also words such as "piss, shit" which are the most typical words related to human excretion and cannot be used casually. In addition, with the development of society, some words about aging, disease, death, poverty, obesity and other topics have naturally become taboo words to a certain extent.

\subsection{The Classification of English Euphemisms}

With the passage of time and language changes, euphemism has become an important communicative language in the Anglo-American society. Some people have divided euphemism into the following categories.

\subsubsection{Euphemisms closely related to taboo words}

There are some taboo things like birth, old, sick, dead, buried, etc. If expressed directly, it will give people a rude, blunt, harsh feeling. On the other hand, if it is expressed indirectly in an elegant, subtle way, it will not be unpleasant. For example, the old people are often referred to as the elderly, senior citizen, venerable people, get on years, and so on.

\subsubsection{Euphemisms Related to Courtesy}

Euphemism is also often used to express words that cannot be said or spoken. When people are not willing to say it directly, euphemism is used to show politeness, which is to avoid stimuli, or to seek cooperation, to commemorate some unpleasant things. For example, people often use big, plump, stout or over-weight instead of fat; use thinner or slim instead of thin; use ordinary, homely or plain to refer to ugly.

\subsubsection{Euphemisms Related to Politics}

In recent years, euphemism has been widely used as a rhetorical device in social activities, political affairs, and business cooperation, and has continued to produce new euphemisms. For instance, a poor nation can be said to be a developing nation; poor people are replaced by low income. In the United States, people refer to blacks as African Americans, Indians as Native Americans, and Mexicans as Mexican Americans, on the one hand, to show equality for everyone, and on the other hand to benefit the unity of all nations.

\subsubsection{Euphemisms Related to Occupation}

In order to decentralize the traditional "low-level occupation", some industry-related euphemisms must be used in life, such as people calling waiter or waitress as dining-room attendants; selling salesman as customer's representative; calling maid as domestic help; The landscape worker is called a landscape architect; the plumber is called a pipe engineer.

\section{THE CONNECTION BETWEEN ENGLISH TABOOS AND EUPHEMISMS}

Taboo and euphemism, as two special linguistic phenomena, are widely found in the languages of countries around the world. Therefore, the two language phenomena-taboo and euphemism, are interdependent, and if there is no taboo, then there is no euphemism. The emergence of euphemism has replaced taboo in language. Due to the changes in society and the development of language, there are different taboo words at different times. The existence of taboo words constantly stimulates the emergence of euphemism, and the two complement each other. Therefore, taboo words and euphemisms are variable. To express the desire to go to the toilet, in order to avoid the use of the word directly referring to the toilet, the word lavatory was used as a euphemism, but as time passed, it developed into a taboo word. On this basis, more euphemisms such as bathroom, washroom, restroom have emerged to express this meaning. 
Another connection between English taboo and euphemism is that both have a strong national character, and each nation has a different culture, so it is difficult to ensure that people of different cultural backgrounds will have the same understanding of the same thing. Therefore, for certain taboo expressions between different ethnic groups, there will be different euphemisms to match them.

\section{THE DIFFERENCES BETWEEN ENGLISH TABOOS AND EUPHEMISMS}

Although taboos and euphemisms are inseparable, they must be two special linguistic phenomena. They differ in meaning and nature, social functions and purposes, and they must not be confused.

\subsection{The Difference of the Meaning between English Taboos and Euphemisms}

\subsubsection{Taboos}

In the previous article, the concept of taboo words was mentioned. Simply speaking, taboo words refer to those words that are tabooed by the public. In English, they are called taboo. The original meaning is the behavior that should be prohibited or avoided. The emergence and formation of taboo words are related to many factors such as social customs, cultural traditions, religious etiquette, ethics, and personal accomplishment.

\subsubsection{Euphemisms}

Both domestic and foreign dictionaries have explanations for euphemism, such as Long man Dictionary of Language Teaching \& Applied Linguistics (2000). The use of a word which is thought to be less offensive or unpleasant $t \mathrm{~h}$ another word. The Collins Dictionary's commentary on euphemism is more specific, as "Euphemism is an inoffensive word or phrase substituted for one considered offensive or hurtful, esp. one concerned with religion, sex, death or excreta." In real life, some things or behaviors should not be expressed in a straightforward manner, but should be replaced with some "better-sounding names". For the taboos in life, people may avoid expressing them, but in social interactions and language communication, sometimes they have to talk about these taboos, so they must find another expression to replace them. This is the social basis of euphemism.

\subsection{The Difference of Social Function of English Taboos and Euphemisms}

The American linguist Samuel Wolff once said: "Language is a guide of social reality". In daily communication, taboos and euphemisms are widely used, but the social functions of the two are quite different. If we have a clear understanding of the nature of language, then we know that taboo words actually have corresponding, straightforward words to indicate their meaning. However, due to the differences in social life concepts, people will have taboos on some things and some languages. Therefore, the concept of taboos is born with social life, and it has a strong sociality. Thus, the social function of taboo words is mainly reflected in three aspects, the first is to express curse and resistance. The second is to express emotions. The last one is about the psychological venting and release of people.

The middle class is the main social foundation of euphemism. The working people at the bottom of the society have low culture and do not have the time and conditions to scrutinize and ponder language. However, they also urgently want to change their own situation. Therefore, in daily communication, people are influenced by the survival rules of society. To improve their social status, people must work harder on language and beautify language, which promotes the emergence of euphemism. Generally speaking, euphemism has two social functions: humility and politeness, avoidance and disguise.

\subsection{The Difference of the Purpose between English Taboos and Euphemisms}

The difference in social function between taboos and euphemisms determines the difference in their purpose of use. It is the application of taboo words in a society that has great limitations. Euphemisms are naturally produced and widely used. In other words, the main purpose of euphemism is to replace taboo words. Therefore, the purpose of euphemism is to avoid taboo, add language literary or cover up some ugly words. For example, in today's economic development, the economic crisis is unwilling to be mentioned in many countries. English-speaking countries will describe the economic crisis as an economic recession, which reflects the vitality of euphemism. 


\section{CONCLUSION}

Language is the carrier of culture and an important part of the national culture. There are many taboos in society. In real life, people always use taboo words for some reasons or things and substitute them in euphemism. Therefore, both taboos and euphemisms are cultural phenomena, which are common phenomena in various languages and exist in every country. Taboos and euphemisms in English are an integral part of the culture. They profoundly and permanently influence the use of the English language. They have similarities and differences, and a more detailed and in-depth understanding of the culture, traditions, and customs of English-speaking countries. Even the details of life, the more correctly the language can be used. By comparing taboos and euphemisms, we can better understand the differences between the two in terms of culture and psychology. Only by conducting in-depth discussions and comparative studies can we reduce cultural conflicts, conduct successful language exchanges, and improve the ability of cross-cultural communication.

\section{BIBLIOGRAPHY}

[1] Fromkin V and Rodman R. An Introduction to Language. New York: CBS College Publishing, 1983.

[2] Zhu Yanju. "Communicative Functions of English Euphemism.", 2010.

[3] Allan,K,K. Burridge. Forbidden Words-Taboo and the Censoring of Language, 2006.

[4] Danglli,L. Euphemism and Lexical Synonymy. Anglisticum Journal, 2004.

[5] 陈申著,语言文化教学策略研究[M]. 北京语言文化大学出版社, 2001.

[6] 郭丽娟. 跨文化交际下的英语禁忌语文化内涵探究[J]. 内江科技, 2010(01).

[7] 刘纯豹. 英语委婉语词典[M]. 江苏教育出版社, 2013.

[8]＼cjkstart喜同清. 委婉语社会语言学分[J]. 西华师范大学学报, 2006.

[9] 王银泉. 禁忌语与委婉语关系之初探[J]. 四川: 四川外语学院学报, 1996.

[10] 向仍东. 浅析英语委婉语的特征、构成及作用. 长沙大学学报, 2005.

[11] 张公瑾,丁石庆. 文化语言学教程[M]. 教育科学出版社, 2004.

\section{AUTHOR'S BIOGRAPHY}

Yang hua, female, English major, studying in sichuan university of science and Engineering, like sports and yoga, cheerful personality, like all interesting things.

Citation: YANG HUA. "A Comparative Study of English Taboos and Euphemisms" International Journal of Humanities Social Sciences and Education (IJHSSE), vol 7, no. 3, 2020, pp. 17-21. doi: http://dx.doi.org/10.20431/2349-0381.0703003.

Copyright: () 2020 Authors. This is an open-access article distributed under the terms of the Creative Commons Attribution License, which permits unrestricted use, distribution, and reproduction in any medium, provided the original author and source are credited. 